\title{
Dynamic Analysis of Money Demand Function in Turkey
}

\author{
Bülent Doğru ${ }^{1} \&$ Mürşit Recepoğlu ${ }^{1}$ \\ ${ }^{1}$ Faculty of Economics and Administrative Sciences, Department of Economics, Gumushane University, Turkey \\ Correspondence: Bülent Doğru, Faculty of Economics and Administrative Sciences, Department of Economics, \\ Gumushane University, Turkey. E-mail: buldogru@gumushane.edu.tr
}

Received: June 19, 2013

Accepted: July 24, 2013

Online Published: August 26, 2013

doi:10.5539/ijef.v5n9p20

URL: http://dx.doi.org/10.5539/ijef.v5n9p20

\begin{abstract}
In this paper, the dynamic determinants of money demand function and the long-run and short-run relationships between money demand, real product and nominal interest rates are examined in Turkey for the time period 1980-2012. In particular we estimate a dynamic specification of a long money demand function based on Keynesian liquidity preference theory to ascertain the relevant elasticity of money demand using DOLS and FMOLS methods. The empirical results of the study show that in Turkey inflation, exchange rates and money demand are co-integrated, i.e., they converge to a long run equilibrium point. In this regard, correction procedure corrects nearly 31 percent of the biases from long run equilibrium in one year. Therefore, the real money demand in Turkey is positively related with income and negatively related with nominal interest rates.
\end{abstract}

Keywords: dynamic ordinary least squares, vector error correction, money demand function

\section{Introduction}

A tremendous growth in variety of new trends and innovations has been seen in financial sector during past three decades. This growth also needed to design reliable monetary policies depending on refresh data. These reasons could explain why similar studies from different countries have appeared in macroeconomic literature on money demand policies. There are many studies on money demand function for both developed and developing countries (Eatzaz and M. Munir, 2000). The macroeconomic modeling of money demand function has a crucial importance for monetary policy. Although there is a consensus that central banks have been deactivated and have little role under an interest rate based monetary policy, the demand for money is still believed to be important in terms of macroeconomic models and monetary policies (Bae and De Jon, 2007).

There is an extensive literature on estimation of money demand function. However most of this literature depends on a stable and linear money demand function. Some of these reputable references are Chow (1966), Laidler (1985, 1977), Lucas (1988), Hoffman and Rasche (1991), Miller (1991), Baba et al. (1992), Kallon, (1992) Stock and Watson (1993), Mehra (1993), Miyao (1996), Choi et al (1998), Ahmet and Munirs (2000), Ball (2001), Anderson and Rasche (2001), Sriram (2001), Nell (2003), Handa (2009) and Drama and Yao (2010). Additions to these studies, recently the dynamic money demand function have been estimated for both country groups and individuals by many notable references: Adam (1992), Bae and De jong (2007), Baba et al (2013), Terasvirta and Eliasson (2001), Chen and Wu (2005), Park and Phillips (1999, 2001), Chang et al. (2001), De Jong (2002) and Asuamah et al (2012). Short-run dynamics of the money demand function has largely been estimated in the framework of "Error Correction Model" (ECM), while the long-run cointegration relationship in nonlinear money demand function and dynamic money demand function are respectively investigated in the framework of "Nonlinear Cointegration Least Squares" (NCLS) developed by Bae and De jong (2007) and Fully Modified OLS (FMOLS) developed by Pedroni (2000, 2001) and Philips ve Moon (2000) and Dynamic OLS (DOLS) developed by Kao ve Chiang (2000).

The money demand function has generally been considered as a linear function and estimated largely by vector error correction (VEC) and Dynamic Ordinary Least Squares (DOLS) methods. The purpose of this study is to estimate money demand function for Turkey both by these methods and Fully Modified OLS (FMOLS). We also compare coefficients of these different models. The distinguished aspect of the study from the relevant literature is that it estimates dynamic money demand function for Turkey using FMOLS method.

The rest of the paper is organized as follows. In section two money demand function is introduced. Data and econometric results are in section 3 . Section four concludes the study. 


\section{Money Demand Function}

Although there is a consensus that money demand function has a little role under Taylor-rule type monetary policy, it is still believed that money demand has a crucial importance for both macroeconomic model and monetary policy. In each country, monetary authorities continue to underline the role of the money demand function on monetary policy operations of the central banks (Bayer, 1998; Lutkepohl et al, 1999; Bae and De Jong, 2007). Studies on monetary policies indicate that monetary policy does not work only through the interest rate channel, but it gives useful information about portfolio allocations either. Many researcher accept that since money supply is largely controlled by the money authorities, money supply curve is drawn parallel to the axis of the nominal interest rate and vertically to the axis of the quantity of money (Papademos and Modigliani, 1990, p.402; Bae and De Jong, 2007) (A vertical line to the plane of interest rate and quantity of money). We conclude that the elasticity of the money supply to the nominal interest rate is zero. In the literature following Lucas (1988), Stock and Watson (1993), Ball (2001) and Bae and De Jon (2007), the long run money demand function is widely shown in the following form:

$$
m_{t}=\beta_{0}+\beta_{1} r_{t}+\mu_{t}
$$

Where $m_{t}$ denotes the logarithm of real money demand and $r_{t}$ is the nominal interest rate. Besides the functional form (1), Allais (1947), Baumol (1952), Tobin (1956) and Bae and De Jon (2007) suggest a log - log model for money demand function to ascertain the relevant elasticities based on the inventory theoretic approach:

$$
m_{t}=\beta_{0}+\beta_{l} \ln \left(r_{t}\right)+\mu_{t}
$$

In this paper we assume validity of Keynesian liquidity preference theory, and consider only logarithmic functional form of money demand function developed by Allais (1947), Baumol (1952) and Tobin (1956) but extended by Miller and Orr (1966) and Bae and De Jon (2007), and includes both income elasticity and interest rate elasticity. Following Bae and De Jon (2007), we consider an individual having an income Y in the form of bonds. We are also assuming that the transaction cost for converting bond into cash is $b$, and that the real value of bonds converted into cash in each time is denoted by $\mathrm{K}$. Then total transaction cost consisting of conversion cost and interest cost on money holding $(\mathrm{K} / 2)$ over the timewill be denoted by the following formulation, in which the first term shows conversion cost and the second term is interest cost on holding money (Bae and De Jon, 2007).

$$
\gamma=b\left(\frac{Y}{K}\right)+r\left(\frac{K}{2}\right)
$$

Optimal real money balances is derived from minimizing the transaction cost with respect to $\mathrm{K}$

$$
\frac{M^{d}}{P}=\frac{K}{2}=\frac{1}{2}\left(\frac{2 b Y}{r}\right)^{1 / 2}
$$

Where $\frac{M^{d}}{P}$ indicates the real money balances. Taking the logarithm of the equation (4), we get equation

written below.

$$
\ln m_{t}=\ln \left(\frac{M^{d}}{P}\right)=\beta_{0}+\beta_{1} \ln (Y)+\beta_{2} \ln (r)+\mu_{t}
$$

Where $\beta_{1}$ and $\beta_{2}$ are constant income and interest rate elasticitiesof money demand. Why we are dealing with logarithmic form of the money demand function in this study is that liquidity trap can be captured easily by this form. In the case of the liqiditiy trap, money demand becomes indefinite at a very low interest rate. Functional form (2) includes lidiqidty trap, because (2) allows the demand function increases to the infinity as the interest rates approaches to zero (Bae and De Jong: 4). Our expectataion about the signs of the coefficients of $\beta_{1}$ and $\beta_{2}$ is positive and negative, respectively.

\section{Data and Empirical Results}

In this study we use the same variables as Bae and De Jong (2005), Ball (2011), Stock and Watson (1993) used in their papers, but we extended the variables up to year 2012. These variables are;

M1: Logarithmic form of the demand of real narrow money balances, equal to $\frac{M 1^{d}}{P}$.

M2: Logarithmic form of the demand of real broad money balances, equal to $\frac{M 2^{d}}{P}$. 
$y$ : Logarithmic form of the real gross national product, equal to GNP/d.

p: Logarithmic form of the price level (P), equal to GNP deflator.

$r$ : Logarithmic form of the nominal interest rate, equal to average of twelve- months commercial paper rate.

All the data used in this paper are delivered from the Central Bank of the Republic of Turkey (CBRT). Some basic descriptive statistics of the variables in logarithmic form which we employed in this study is presented in table 1, while the general trends of variables is shown in figure 1 . Table 1 indicates that maximum volatility happens in narrow and broad money demand variables, and that the value between minimum and maximum is again valid for variable M1 equal to logarithm of real money balance.

Table 1. Descriptive statistics of the variables in logartimic form

\begin{tabular}{lccccc}
\hline & $\boldsymbol{M 1}$ & $\boldsymbol{M}$ & $\boldsymbol{y}$ & $\boldsymbol{P}$ & $\boldsymbol{r}$ \\
\hline Observations & 32 & 32 & 32 & 32 & 32 \\
Mean & 17.99646 & 19.53874 & 24.93311 & 3.518646 & 3.791020 \\
Maximum & 24.04672 & 25.41066 & 25.37596 & 4.926964 & 4.474948 \\
Minimum & 11.96622 & 13.16635 & 24.51147 & 1.665818 & 2.725890 \\
Std. Dev. & 4.221456 & 4.253382 & 0.274773 & 1.035389 & 0.566015 \\
\hline
\end{tabular}

Source: CBRT electronic data service.
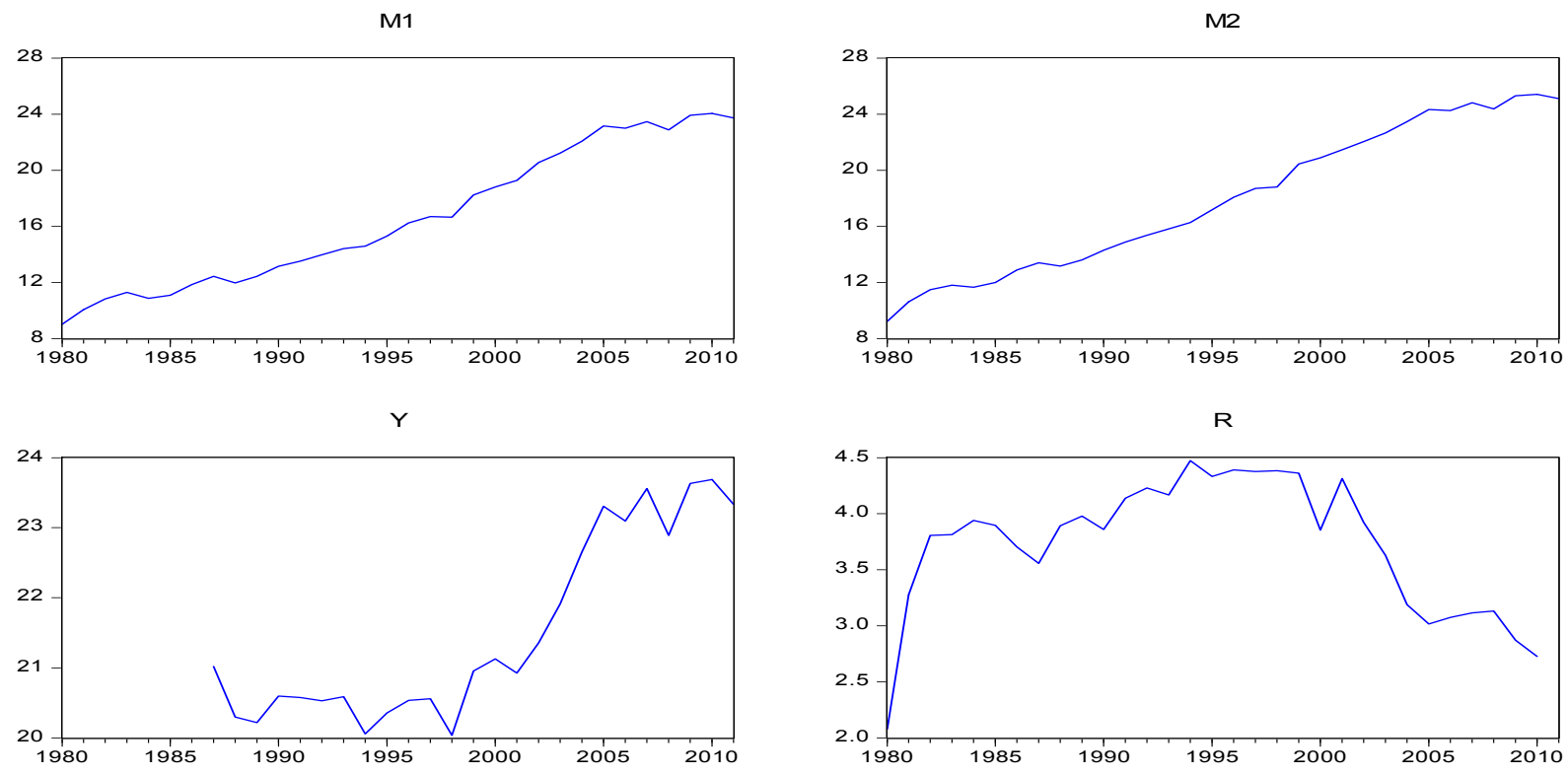

Figure 1. General trend of variables used in the study

Source: Author's drawings.

\subsection{Unit Root Test Result}

Before estimating equation (5) we will firstly investigate stationarity and level of integration of time series which we employ in the model. The integration degree of the series and the choice of appropriate cointegration method is important to make appropriate econometric analysis (Güloğlu and İvrendi, 2010: 9). Besides some potential problems of using non-stationary data we know that non-stationary time series also can cause spurious (non-sense) regression results, as noted by Granger and New bold (1974). For this purpose we conduct two unit root tests to the logarithmic variables of the model (5): Augmented Dickey fuller (ADF) test and Kwiatkowski-Phillips-Schmidt- Shin (KPSS) test (Kwiatkowski et al. 1992). The test results are presented in Table 2 and 3.The ADF and KPSS test results show that all the variables have unit root in their level values but become stationary in their first difference, i.e. they are integrated as I (1). Also this result can be seen from the figure 1 indicating that each variable has a non-stationary trend in level. 
Table 2. ADF test results ${ }^{\text {a }}$

\begin{tabular}{ccccccc}
\hline & \multicolumn{3}{c}{ Level } & \multicolumn{2}{c}{ First Difference } \\
\cline { 2 - 6 } & $\begin{array}{c}\tau(\text { No intercept } \\
\text { no trend) }\end{array}$ & $\tau_{\mu}$ (Intercept) & $\begin{array}{c}\tau_{\mathrm{t}} \text { (Intercept and } \\
\text { Trend) }\end{array}$ & $\begin{array}{c}\tau \text { (No intercept } \\
\text { no trend) }\end{array}$ & $\begin{array}{c}\tau_{\mu} \text { (Intercept) } \\
\tau_{\mathrm{t}} \text { (Intercept and } \\
\text { Trend }\end{array}$ \\
\hline $\boldsymbol{M 1}$ & 4.51 & -0.51 & -2.42 & -1.52 & $-5.65^{*}$ & $-5.54^{*}$ \\
$\boldsymbol{M 2}$ & -0.76 & -2.72 & $-3.60^{* *}$ & -0.61 & $-5.61^{*}$ & 0.71 \\
$\boldsymbol{y}$ & 1.00 & -0.29 & -2.68 & $-5.34^{*}$ & $-5.76^{*}$ & $-5.61^{*}$ \\
$\boldsymbol{r}$ & -0.00 & -2.65 & -1.62 & $-6.14^{*}$ & $-6.00^{*}$ & $-6.36^{*}$ \\
\hline
\end{tabular}

${ }^{\mathrm{a}} \mathrm{H}_{0}$ : $\mathrm{I}(1)$ is tested against alternative hypothesis $\mathrm{H}_{1}: \mathrm{I}(0)$. The order of the first difference terms is 3 .

Notes: Lag lengths are selected automatically according to Akaike Info Criterion.

The critical values of test statistics $\left(\tau, \tau_{\mu}, \tau_{\mathbf{t}}\right)$ are tabulated in Fuller (1976) and MacKinnon (1996).

${ }^{*}$ and ${ }^{* *}$ show statistically significant at $1 \%$ and $5 \%$ respectively.

Table 3. KPSS unit roots test resultsa

\begin{tabular}{ccccc}
\hline & \multicolumn{3}{c}{ Level } & \multicolumn{2}{c}{ First Difference } \\
\cline { 2 - 5 } & $\tau_{\mu}($ Intercept $)$ & $\tau_{\mathrm{t}}$ (Intercept and Trend $)$ & $\tau_{\mu}($ Intercept $)$ & $\tau_{\mathrm{t}}($ Intercept and Trend $)$ \\
\hline $\boldsymbol{M 1}$ & 0.74 & 0.21 & $0.11^{*}$ & $0.13^{* *}$ \\
$\boldsymbol{M} 2$ & 0.74 & 0.22 & $0.21^{*}$ & $0.13^{* *}$ \\
$\boldsymbol{y}$ & $0.61^{* *}$ & 0.75 & $0.27^{*}$ & $0.13^{*}$ \\
$\boldsymbol{r}$ & 0.21 & $0.19^{* *}$ & $0.56^{*}$ & $0.8^{*}$ \\
\hline
\end{tabular}

${ }^{\mathrm{a}} \mathrm{H}_{0}: \mathrm{I}(0)$ is tested against alternative hypothesis $\mathrm{H}_{1}: \mathrm{I}(1)$.

Notes: Critical values are taken from Kwiatkowski-Phillips-Schmidt-Shin (1992) Table 1. ${ }^{*}$ and ${ }^{* *}$ show statistically significant at $1 \%$ and $5 \%$ respectively.

Since all series are non-stationary, then there may be both short- run and long-run relationships between these variables. In order to examine the existence of a short-run relationship, we should check the relevant coefficients in the Vector Autoregressive (VAR) model. For this purpose we firstly apply a co-integration test to the data to check the existence of a long-run relationship between variables.

\subsection{Co-integration Test Result}

It is known that a linear combination of non-stationary time series could make a long run equilibrium point, namely they move cointegrated over the time. In this part we are using Johansen co-integration test to examine whether the variables are co-integrated with each other. If one or more linear combination of individually non-stationary series is stationary then these series may be co-integrated. This means that these series cannot move too far away from each other (Dickey, Jansen and Thorton, 1991:58). To apply Johansen test, we must determine lag length of unrestricted VAR model within five different lag selection criterions including likelihood Ratio (LR), Final Prediction Error Criterion (FPE), Akaike information criterion (AIC), Schwarz information criterion (SC) and Hannan-Quinn information criterion (HQ). The maximum lag number selected is 4. Lag order selection criteria results are shown in table 4. We also add three dummies (D94, D01 and D08) as exogenous variables to the VAR model to consider the unpredicted shock effects of three economic crises occurred in 1994, 2001 and 2008 respectively. The dummy variables D94, D01 and D08 are unity for year 1994, 2001 and 2008 and zero otherwise. According to table 4, most of the lag selection criterions suggest lag order as 2.

Table 4. Lag selection criteria results

\begin{tabular}{cccccc}
\hline Lag & LR & FPE & AIC & SC & HQ \\
\hline 0 & 0 & NA & 0.052289 & 5.562410 & 5.711770 \\
1 & 1 & $116.7545^{*}$ & $8.85 \mathrm{e}-05^{*}$ & $-0.834748^{*}$ & $-0.237309^{*}$ \\
2 & 2 & 9.563770 & 0.000113 & -0.670423 & 0.375096 \\
3 & 3 & 7.457716 & 0.000161 & -0.516194 & 0.977404 \\
4 & 4 & 2.098393 & 0.000463 & 0.084035 & 2.025713 \\
\hline
\end{tabular}

* indicates lag order selected by the criterion. LR: sequential modified LR test statistic (each test at $5 \%$ level), FPE: Final prediction error, AIC: Akaike information criterion, SC: Schwarz information criterion, HQ: Hannan-Quinn information criterion. 
We employ Johansen Test method to determine number of cointegrating vectors with two statistics: The trace and maximum eigenvalue statistics. The trace statistics tests the null hypothesis that the number of co-integrating vectors is less than or equal to $r$, where $r$ is 0,1 or 2 against general alternative, while the maximum eigenvalue statistics tests the null hypothesis that $\mathrm{r}=0,1$ or 2 against the alternative hypothesis indicating that $\mathrm{r}=1,2$, or 3 . The critical values of the tests are tabulated from Johansen and Juselius (1990). Table 5 presents the results of Johansen Cointegration Test using the maximum eigenvalue and the trace tests. Both the maximum eigenvalue and trace tests results shown in table 4 suggest one co-integration relationship among three variables

Table 5. Tests results for co-integration rank

\begin{tabular}{ccccccccc}
\hline $\mathrm{H}_{0}$ & $\mathrm{H}_{\mathrm{A}}$ & $\lambda_{\mathrm{i}}$ & $\lambda_{\max }$ & $\mathrm{CV} 95 \%$ & $\mathrm{H}_{0}$ & $\mathrm{H}_{\mathrm{A}}$ & Trace & $\mathrm{CV} 95 \%$ \\
\hline $\mathrm{r}=0$ & $\mathrm{r}=1$ & 0.644078 & 21.69390 & 21.13162 & $\mathrm{r}=0$ & $\mathrm{r} \geq 1$ & 49.60239 & 29.79707 \\
$\mathrm{r} \leq 1$ & $\mathrm{r}=2$ & 0.504434 & 14.14317 & 14.26460 & $\mathrm{r} \leq 1$ & $\mathrm{r} \geq 2$ & 15.30849 & 15.49471 \\
$\mathrm{r} \leq 2$ & $\mathrm{r}=3$ & 0.465765 & 13.16532 & 3.841466 & $\mathrm{r} \leq 2$ & $\mathrm{r} \geq 3$ & 13.16532 & 3.841466 \\
\hline
\end{tabular}

Critical values are tabulated from Table 1 of Osterwald and Lenum (1992). * shows significance level at $5 \%$.

\subsection{Estimation Results}

We find that there is only one co-integrating vector between variables indicating that we can estimate long-run relationship between variables using vector error correction (VEC), DOLS and FMOLS techniques. For this purpose in this section, the long-run dynamics of money demand function of equation (5) is estimated by VEC, DOLS and FMOLS methods.

A VECM model with our variables and one lag is simply stated as follow:

$$
d\left(m_{t}\right)=\theta_{0}+\beta_{0} * d\left(m_{t-1}\right)+\beta_{1} * d\left(y_{t-1}\right)+\beta_{2} * d\left(r_{t-1}\right)+\beta_{3} * E C(-1)+\varepsilon_{t}
$$

Where; $\mathrm{m}, \mathrm{r}$ and $\mathrm{y}$ are at the first differenced variables, and $m_{t}$ are equal to $\mathrm{m}_{1}$ or $\mathrm{m}_{2}$. $\theta_{0}$ indicates constant coefficient and $\beta_{0}, \beta_{1}$ and $\beta_{2}$ shows short run causalities, while $\beta_{3}$ is the long run coefficient of the VEC model. $E C(-1)$ is the one period lag residual of co-integrating vectors of the long run model given below:

$$
m_{t}=\theta_{0}+\theta_{1} * r_{t}+\theta_{2} * y_{t}+\vartheta_{t}
$$

Where $E C(-1)$ indicates the adaptation rate to the long run equilibrium. It corrects disequilibrium and leads variables $\mathrm{m}, \mathrm{r}$ and $\mathrm{y}$ of the system to converge to its long run equilibrium point. Hence, we expect that the sign of $\beta_{3}$ should be negative because the coefficient of $\beta_{3}$ shows what rate it corrects the previous period disequilibrium of the system.

VEC estimation result of the equation (6) with one lag is reported in Table 6. The coefficient of error correction term $E C(-1)$ is -0.34 which is negative and significant as expected. It means that system corrects its previous period disequilibrium at a speed of approximately 34 percent yearly. In other saying, almost $34 \%$ of deviation from long run equilibrium is smoothed in one year. Moreover, this result provides evidence that income and nominal interest rate cause money demand in long run.

\begin{tabular}{|c|c|c|c|c|}
\hline \multirow[b]{2}{*}{$\begin{array}{c}\text { Explanatory } \\
\text { variables }\end{array}$} & \multicolumn{2}{|c|}{ VEC1: Dependent variable: $\mathrm{m} 1$} & \multicolumn{2}{|c|}{ VEC2: Dependent variable: $\mathrm{m} 2$} \\
\hline & Coefficient & Prob. & Coefficient & Prob. \\
\hline$E C(-1)$ & $-0.345680^{*}$ & 0.0000 & $-0.081167^{*}$ & 0.0097 \\
\hline$d\left(m_{t-1}\right)$ & $0.599926^{* *}$ & 0.089 & $1.318553^{*}$ & 0.0027 \\
\hline$d\left(y_{t-1}\right)$ & $0.873500^{*}$ & 0.059 & $1.733377^{*}$ & 0.0002 \\
\hline$d\left(r_{t-1}\right)$ & $-0.992656^{*}$ & 0.0572 & $-1.033190^{*}$ & 0.0020 \\
\hline Constant & $0.769424^{*}$ & 0.0000 & -0.016065 & 0.9361 \\
\hline \multicolumn{3}{|c|}{ Co-integration equation: } & \multicolumn{2}{|c|}{ Co-integration equation: } \\
\hline
\end{tabular}

Table 6. Error correction model estimation result

${ }^{* *}$ indicates in order $10 \%$ and $5 \%$ significance level. 
According to estimation result of co-integration equations (long-run relationship) under the table 6 there is a strong and significant long run relationship between $m, r$ and $y$. It implies that a percentage increase in income is associated with a 5.65 percentage increase in M1 and 6.46 percentage increase in M2. Also, a percentage increase in nominal interest rate is associated with a 5.15 percentage decrease in M1 and 10.66 percentage decrease in M2. The signs of the short run coefficients are the same as in the long run except the constant term in VEC2 model. It is clearly seen that the short-run elasticities have values lower than the long run elasticities for both narrow and braod money demand models (VEC1 and VEC2 models).

Furthermore, The Stock-Watson's DOLS model is generally used in small samples and gives a robust result compared to alternative techniques. The presence of leads and lags for different variables eliminates the bias of simultaneity within a sample and DOLS estimates and provide better approach to normal distribution (Baba et al, 2013:23). DOLS model with dependent variable $y_{t}$ and independent variable $x_{t}$ is specified as below:

$$
y_{t}=\varphi_{0}+\varphi x_{t}+\sum_{j=-m}^{n} d \Delta x_{t-j}+\varepsilon_{t}
$$

Where $\mathrm{n}$ and $\mathrm{m}$ show lag and lead length, and $\varphi$ indicates the long run effect of a change in $\mathrm{x}$ on $\mathrm{y}$. The reason why lag and lead terms are included in DOLS model is that they have the role to make its stochastic error term independent of all past innovations in stochastic repressors (Baba et al, 2013:23). Equation (5) is specified in a DOLS framework as follows:

$$
m_{t}=\theta_{0}+\theta_{1} y_{t}+\theta_{2} r_{t}+\sum_{k=-K_{i}}^{K_{i}} \omega_{k} \Delta y_{t}+\sum_{k=-K_{i}}^{K_{i}} \tau_{k} \Delta r_{t}+\varepsilon^{*}{ }_{t}
$$

Where $-K_{i}$ and $K_{i}$ shows leads and lags. The optimal lag structure can be determined by using AIC (Akaike Information Criteria), SC (Schwarz Criteria) or using the values of $\sqrt{N}$ recommended by stock-Watson (1993) for DOLS approach, where N is number of observation. According to Stock-Watson's approach the optimal lag should be equal to $\sqrt{33} \cong 5.74$. Since we have limited observation, we prefer AIC and SC criteria to determine lag length. FMOLS and DOLS estimation result is presented in table 7 suggesting that in both FMOLS and OLS models which do not include trend model, the interest rate and real national product are negatively and positively related to narrow (M1) and broad (M2) money demand as the economic theory and many other empiric studies pre-supposed. In both models coefficients are significant at least at 5\% percent error level. Estimation result of linear models contradicts with economic theory, so we take into consideration only estimation results of the models not including linear trend.

More specifically, the interpretation of coefficients estimated in table 7 is as follows: The DOLS (FMOLS) estimator shows that 1 percent increase in the nominal interest rates and real product, respectively decreases narrow money demand (M1) by 2.18 (2.38) and increases M1 by 1.24 (1.26) percent. However, when dependent variable is M2 then the DOLS (FMOLS) estimator indicates that 1 percent increase in the nominal interest rates and real product respectively decrease narrow money demand (M2) by 2.18 (2.38) and increases M2 by 1.24 (1.26) percent.

Table7. Co-integration estimation: DOLS and FMOLS estimation result based on econometric model

\begin{tabular}{ccccccccc}
\hline & \multicolumn{3}{c}{ Dependent Variable: M1 } & \multicolumn{3}{c}{ Dependent Variable M2 } \\
\cline { 2 - 9 } & \multicolumn{2}{c}{ Trend: None } & \multicolumn{2}{c}{ Trend: Linear } & \multicolumn{2}{c}{ Trend: None } & \multicolumn{2}{c}{ Trend: Linear } \\
\hline Estimation Method & $\mathrm{r}$ & $\mathrm{y}$ & $\mathrm{r}$ & $\mathrm{y}$ & $\mathrm{r}$ & $\mathrm{y}$ & $\mathrm{r}$ & $\mathrm{y}$ \\
DOLS & $-2.18^{* *}$ & $1.24^{*}$ & $8.48^{*}$ & $6.33^{*}$ & $-1.71^{* *}$ & $1.23^{*}$ & $10.85^{* *}$ & $7.21^{* *}$ \\
FMOLS & $-2.38^{*}$ & $1.26^{*}$ & $7.08^{*}$ & $5.70^{*}$ & $-1.96^{* *}$ & $1.25^{*}$ & $8.60^{*}$ & $6.21^{*}$ \\
\hline
\end{tabular}

Note: Leads and lags were set to 1 and 2 for DOLS estimators. ${ }^{* *}$ and $*$ shows statistical significanceat 5 and 1 percent level.

Estimation results also suggest that the impact of interest rates on money demand is greater than that of the real product in Turkey. We conclude that the coefficients gained from long run estimation of money demand function by Johansen co-integration method is larger than coefficients estimated by FMOLS and DOLS techniques. 


\section{Conclusion}

The main aim of this paper is to investigate the dynamic determinants of money demand function proposed by Bae and De Jon (2005) but based on Keynesian liquidity reference theory for Turkey covering the time period from 1980 to 2012. The long and short run coefficients of the money demand function is estimated by vector error correction, dynamic ordinary least squares (DOLS) and fully modified OLS (FMOLS) techniques.

The estimation result of the dynamic money demand function is consistent with the earlier empirical findings and suggests that there is a long-run relationship between money demand, real product and nominal interest rate as economic theory anticipates. But the long run-coefficients estimated from FMOLS and DOLS is smaller than that of the Johansen co-integration vectors. Nevertheless, real money demand in Turkey is positively related with real product and negatively related with nominal interest rates. Correction procedure is very high, and corrects nearly 34 percent of the biases from long run equilibrium in one year due to shocks in the short run.

\section{References}

Adam, C. (1992). On the dynamic specification of money demand in Kenya. Journal of African Economies, 1, 233-270.

Anderson, R. G., \& Rasche, R. H. (2001). The remarkable stability of monetary base velocity in the United States, 1919-1999. Federal Reserve Bank of St. Louis Working Paper.

Asuamah, S. Y., Tandoh, F., \& Mahawiya, S. (2012). Demand for money in Ghana: An empirical assessment, advances in arts. Social Sciences and Education Research, 2(7).

Baba, Y., Hendry, D. F., \& Starr, R. M. (1992). The demand for $\mathrm{m} 1$ in the USA, 1960-1988. The Review of Economic Studies, 59, 25-61. http://dx.doi.org/10.2307/2297924

Bae, Y., \& De Jong, R. M. (2007). Money demand function estimation by nonlinear cointegration. Journal of Applied Econometrics, 22(4), 767-793. http://dx.doi.org/10.1002/jae.915

Ball, L. (2001). Another look at long-run money demand. Journal of Monetary Economics, 47, 31-44. http://dx.doi.org/10.1016/S0304-3932(00)00043-X

Chang, Y., Park, J. Y., \& Phillips, P. C. B. (2001). Nonlinear econometric models with cointegrated and deterministically trending regressors. Econometrics Journal, 4(1), 1-36. http://dx.doi.org/10.1111/1368-423X.00054

Chen, S. L., \& Wu, J. L. (2005). Long-run money demand revisited: Evidence from a non-linear approach. Journal of International Money and Finance, 24, 19-37. http://dx.doi.org/10.1016/j.jimonfin.2004.10.004

Choi, C. Y., Ling, H., \& Masao, O. (2008). Robust estimation for structural spurious regressions and a hausman-type cointegration test. Journal of Econometrics, 142, 327-351. http://dx.doi.org/10.1016/j.jeconom.2007.06.003

Chow, G. C. (1966). On the long-run and short-run demand for money. Journal of Political Economy, 74. http://dx.doi.org/10.1086/259130

Drama, B. H. G., \& Yao, S. (2010). The demand for money in Cote d'Ivoire: Evidence from the cointegration test. International Journal of Economics and Finance, 3(1).

Eatzaz, A., \& Munirs, M. (2000). An analysis of money demand in Pakistan. Pakistan Economic and Social Review, 38(1), 47-67.

Ewing, B. T., \& Payne, J. E. (1999). Long-run money demand in Chile. Journal of Economic Development, 24(2), 177-190.

Granger, C. W. J., \& Newbold, P. (1974). Spurious regressions in economics. Journal of Econometrics, 2(2), 111-120. http://dx.doi.org/10.1016/0304-4076(74)90034-7

Güloğlu, B., \& İvrendi, M. (2010). The effects of monetary policy shocks on exchange rate: A structural VECM with long-run restrictions.

Handa, J. (2009). Monetary Economics. New York: Routledge Taylor \& Francis Group.

Hoffman, D. L., \& Rasche, R. H. (1991). Long-run income and interest elasticities of money demand in the United States. The Review of Economics and Statistics, 73(4), 665-674. http://dx.doi.org/10.2307/2109405

Kallon, K. (1992). An econometric analysis of money demand in Ghana. Journal of Developing Areas, 26, 475488. 
Laidler, D. (1977). The demand for money: theories and evidence (2nd ed.). New York: Harper and Row.

Laidler, D. E. W. (1985). The demand for money: Theories, evidences, and problems. New York: Harper and Row.

Lucas, Jr. R. E. (1988). Money demand in the United States: A quantitative review. Carnegie-Rochester Conference Series on Public Policy, 29, 1061-1079. http://dx.doi.org/10.1016/0167-2231(88)90009-7

Mehra, Y. P. (1993). The stability of the $\mathrm{m} 2$ demand function: Evidence from an error-correction model. Journal of Money, Credit, and Banking, 25(3), 455-460. http://dx.doi.org/10.2307/2077774

Miller, S. M. (1991). Monetary dynamics: An application of cointegration and error-correction modeling. Journal of Money, Credit, and Banking, 23(2), 139-154. http://dx.doi.org/10.2307/1992773

Miyao, R. (1996). Does a cointegrating $\mathrm{m} 2$ demand relation really exist in the United States? Journal of Money, Credit, and Banking, 28(3), 365-380. http://dx.doi.org/10.2307/2077980

Nell, K. S. (2003). The stability of M3 money demand and monetary growth targets: The case of South Africa. Journal of Development Studies, 39, 151-180. http://dx.doi.org/10.1080/00220380412331322861

Park, J. Y., \& Phillips, P. C. B. (1999). Asymptotics for nonlinear transformations of integrated time series. Econometric Theory, 15(3), 269-298. http://dx.doi.org/10.1017/S0266466699153015

Park, J. Y., \& Phillips, P. C. B. (2001). Nonlinear regressions with integrated time series. Econometrica, 69(1), 117-161. http://dx.doi.org/10.1111/1468-0262.00180

Pedron, P. (2000). Fully modified OLS for heterogeneous cointegrated panels. Advances in Econometrics, 15, 93-130. http://dx.doi.org/10.1016/S0731-9053(00)15004-2

Pedroni, P. (2001). Purchasing power parity tests in cointegrated panels. Review of Economics and Statistics, 83, 727-731. http://dx.doi.org/10.1162/003465301753237803

Sriram, S. S. (2001). A survey of recent empirical money demand studies. IMF Staff Papers, 47(3), 334-365.

Stock, J. H., \& Watson, M. (1993). A simple estimator of cointegration vectors in higher order integrated systems. Econometrica, 61, 783-820. http://dx.doi.org/10.2307/2951763

Terasvirta, T., \& Eliasson, A. C. (2001). Non-linear error correction and the uk demand for broad money. Journal of Applied Econometrics, 16, 277-288. http://dx.doi.org/10.1002/jae.611

Note

Note 1. This study was presented in the 14th International Symposium on Econometrics Operation Research and Statistics in Bosnia Herzegovina, $24^{\text {th }}$ May 2013.

\section{Copyrights}

Copyright for this article is retained by the author(s), with first publication rights granted to the journal.

This is an open-access article distributed under the terms and conditions of the Creative Commons Attribution license (http://creativecommons.org/licenses/by/3.0/). 